\title{
KARAKTERISTIK SIFAT FISIKA DAN KIMIA TAKAKURA COMPOSTING ASAL KULIT PISANG GOROHO MELALUI UJI KERJA KULTUR KERING BAL (BAKTERI ASAM LAKTAT)
}

\author{
Desi Arisanti ${ }^{1)}$, Satria Wati Pade ${ }^{2)}$ \\ ${ }^{1,2}$ Program Studi Teknologi Hasil Pertanian, Politeknik Gorontalo \\ Email: desiarisanti@poligon.ac.id ${ }^{1)}$
}

\begin{abstract}
ABSTRAK
Pisang goroho merupakan tanaman yang memiliki banyak kegunaan serta memiliki kandungan kimia yang beragam seperti kalium, magnesium, fosfor, kalsium, dan besi serta keberadaannya berlimpah di daerah Gorontalo. Kandungan kimia ini tidak hanya terdapat dalam buahnya, tetapi kulitnya pun mempunyai komposisi yang tidak jauh berbeda. Tingginya ketersediaan kulit pisang goroho serta unsur hara yang terkandung di dalamnya membuat bahan tersebut memiliki potensi untuk diolah menjadi pupuk organik. Salah satu faktor yang mempengaruhi kualitas pembuatan pupuk organik adalah jenis mikroba yang aktif selama proses berlangsung. Dalam penelitian ini aktivator yang digunakan yaitu BAL (Bakteri Asam Laktat) yang terdapat dalam minuman yogurt. Inokulum BAL yang digunakan bukan dalam bentuk cair, namun aplikasi BAL kultur kering. Pada prinsip dasarnya proses pembuatan kultur kering meliputi tahapan penyiapan starter, pembuatan starter cair aktif, tahapan sentrifugasi dan homogenisasi dengan bahan pengisi. Penggunaan bahan pengisi ini untuk menjaga viabilitas sel BAL dari pengeringan. Setelah menjadi kultur kering bioaktivator tersebut diaplikasi dalam pupuk organik kulit pisang goroho. Metode pengomposan yang digunakan dalam penelitian ini metode Takakura. Tujuan dari penelitian ini adalah untuk membuat dan menganalisis kualitas pupuk organik yang dihasilkan dengan menggunakan bioktivator dekomposisi kultur kering BAL dengan variasi dosis. Beberapa parameter penelitian yang mengacu pada mutu pupuk organik menurut SNI 19-7030-2004 yang meliputi pH, kadar air kadar abu. Faktor Perlakuan dari penelitian ini 2 taraf faktor yaitu faktor variasi konsentrasi biaktivator BAL dan faktor suhu. Variasi dosis kultur kering BAL terdiri dari 3 taraf yaitu Kontrol, 20\%, 30\%, dan $40 \%$ dari bobot bahan organik dan suhu pengomposan terdiri dari 450C,500C,600C. Berdasarkan hasil penelitian kadar abu terbaik dengan variasi konsentrasi kultur BAL pada perlakuan K3 (81,53\%), variasi suhu $(65,81 \%)$; Kadar air terbaik dengan variasi konsentrasi kultur BAL pada perlakuan K3 (27,78\%), variasi suhu S3 $(65,81 \%)$; namun untuk nilai $\mathrm{pH}$ pada kompos tidak sesuai dengan SNI kompos.
\end{abstract}

\section{Kata kunci: Pisang Goroho,Kultur Kering BAL, Kadar Air,Kadar Abu,pH}

\section{ABSTRACT}

Goroho Banana is a plant that has many uses and has various chemical contents such as potassium, magnesium, phosphorus, calcium, and iron and its abundant presence in Gorontalo. The chemical content is not only found in the fruit, but the skin also has a composition that is not much different. The high availability of the goroho banana peel and the nutrients contained in it makes it have the potential to be processed into organic fertilizer. One of the factors that influence the quality of making organic fertilizer is the type of microbes that are active during the process. In this study the activator used was BAL (Lactic Acid Bacteria) contained in yogurt drinks. BAL inoculum used is not in liquid form, but the application of dry culture BAL. Basically, the process of making dry culture includes the preparation stages of the starter, the manufacture of an active liquid starter, the stages of centrifugation and homogenization with fillers. The use of this filler is to maintain the viability of BAL cells from drying out. After becoming a dry culture, the bioactivator is applied in organic fertilizer of goroho banana peel. The composting method used in this study is the Takakura method. The purpose of this research is to make and analyze the quality of organic fertilizer produced by using a LAB dry decomposition bioctivator with varying doses. Some research parameters that refer to the quality of organic fertilizer according to SNI 19-7030-2004 include pH, moisture content of ash. Treatment Factors from this study were 2 factor levels, namely variations in BAL biactivator concentration and temperature factors. The variation of BAL dry culture dose consists of 3 levels, namely Control, 20\%, 30\%, and 40\% of the weight of organic matter and composting temperature consists of 450C, 500C, 600C. Based on the results of the research, the best ash content with variations in BAL culture concentrations in K3 treatment (81.53\%), temperature variations (65.81\%); The best water content with variations in BAL culture concentrations in K3 treatment (27.78\%), temperature variations S3 (65.81\%); however, the pH value for compost is not in accordance with SNI compost.

Keywords: Goroho Banana, BAL Dry Culture, Water Rate, Ash Rate, pH. 


\section{PENDAHULUAN}

Pengunaan pupuk organik bertujuan untuk mempertahankan kualitas tanah yang terus menerus digunakan untuk lahan pertanian. Penggunaan bahan organik seperti seperti sisa tanaman banyak diaplikasikan pada lahan budidaya. Pisang goroho merupakan tanaman yang memiliki banyak kegunaan serta memiliki kandungan kimia yang beragam seperti kalium, magnesium, fosfor, kalsium, dan besi serta keberadaannya berlimpah di daerah Gorontalo. Kandungan kimia ini tidak hanya terdapat dalam buahnya, tetapi kulitnya pun mempunyai komposisi yang tidak jauh berbeda. Tingginya ketersediaan kulit pisang goroho serta unsur hara yang terkandung di dalamnya membuat bahan tersebut memiliki potensi untuk diolah menjadi pupuk organik.

Salah satu faktor yang mempengaruhi kualitas pembuatan pupuk organik adalah jenis mikroba yang aktif selama proses berlangsung. Kondisi optimum bagi aktivitas mikroba perlu diperhatikan selama proses pengomposan, misalnya aerasi, media tumbuh dan sumber makanan yang berasal dari tanaman atau limbah tanaman yang digunakan. Aktivator pengomposan telah banyak beredar di pasaran. Bakteri Asam Laktat (BAL) merupakan bakteri yang menguntungkan yang bisa mendekomposisi bahan organik. ,pengunaan BAL masih sebatas untuk minuman makanan fungsional, belum adanya inovasi pemanfaatan BAL untuk skala luas. Pada penelitian ini akan dicoba memanfaatkan BAL yang terdapat dalam minuman yogurt sebagai bioaktivator dalam dekomposisi kulit pisang goroho menjadi pupuk organik atau kompos. Inokulum BAL yang digunakan bukan dalam bentuk cair, namun aplikasi BAL kultur kering. Dengan dimanfaatkan BAL dalam bentuk aplikasi kultur kering, diharapkan mikroba dapat terlindungin dari kekeringan dan kematian. Metode pengomposan yang digunakan dalam penelitian ini metode Takakura. Pengomposan dengan metode yang mudah diaplikasikan, biaya yang relatif murah serta hasil kompos yang berkualitas baik. .

Berdasarkan latar belakang di atas, maka tujuan penelitian ini adalah menganalisis kualitas pupuk organik yang dihasilkan dengan menggunakan bioktivator dekomposisi kultur kering BAL dengan variasi dosis. Beberapa parameter penelitian yang mengacu pada mutu pupuk organik menurut SNI 19-7030-2004 yang meliputi pH,kadar air, kadar abu pupuk kompos.

\section{METODOLOGI}

Alat : pH meter, wadah pengomposan, timbangan dengan ketelitian 0,001 g, cawan porselen, gelas piala, tanur, labu erlemeyer, oven, pipet, buret, plastik transparansi, gunting
Bahan : Kulit pisang goroho, yogurt plain. yaitu tepung terigu sebagai bahan pengisi BAL, gula pasir. Peralatan yang digunakan untuk penelitian ini adalah.

\subsection{Metode Penelitian}

Penelitian ini menggunakan metode rancangan acak lengkap (RAL) dengan dua factor yaitu tiga perlakuan perbandingan tepung terigu dan tepung ubi kayu yaitu faktor variasi dosis BAL dan suhu selama pengomposan. Variasi dosis kultur kering BAL terdiri dari 3 taraf yaitu Kontrol, 20\%, $30 \%$, dan $40 \%$ dari bobot bahan organik. Variasi suhu terdiri dari tiga taraf yaitu 450C,500C,600C. Masing-masing perlakuan diulang sebanyak 3 (Tiga) kali ulangan. Data yang dihasilkan kemudian diolah menggunakan uji analisa sidik ragam untuk melihat pengaruh perlakuan uji lanjut BNT untuk mengetahui sejauh mana perbedaan dari masingmasing perlakuan.

\subsection{Prosedur Kerja}

Penelitian ini diawali dengan membuat kultur kering BAL yang akan digunakan sebagai bioaktivator dalam proses pengomposan. Tahapan pertama dimulai dengan penyiapan starter BAL, pembuatan starter cair aktif, kemudian tahapan sentrifugasi dengan kecepatan $1500 \mathrm{rpm}$ selama 30 menit, endapan sel BAL yang terbentuk dicampur dan dihomogenisasi dengan bahan pengisi yang sebelumnya telah disterilisasi pada suhu 121OC selama 15 menit dengan ratio tepung- kultur 1:1. Adonan kemudian disebar tipis pada loyang pengering, lalu dikering anginkan dan akhirnya digerus hingga berbentuk serbuk. Kultur kering BAL siap diaplikasikan dalam pembuatan pupuk organik.

Tahap kedua pada penelitian ini adalah pembuatan pupuk organik pisang goroho. Kulit pisang goroho diambil dari limbah industri rumah tangga pisang goroho yang terdapat di daerah Gorontalo. Bahan dibersihkan dari kotoran yang menempel, dicuci dengan air mengalir, kemudian ditiriskan hingga kering. Kulit pisang goroho yang sudah kering dipotong kecil-kecil dengan ukuran $1 \mathrm{~cm}$. Bahan-bahan lain yang digunakan dalam pembuatan pupuk organik serta bioaktivator dipersiapakan seperti gula pasir, sekam, kardus Proses dekomposisi dilakukan selama satu bulan dengan melakukan pengendalian setiap minggu hingga 1 bulan. Metode pengomposan menggunakan Metode Takakura. Tahap ketiga penelitian adalah uji karakteristik akhir pupuk kompos seperti pH, kadar air, kadar abu. 


\section{HASIL DAN PEMBAHASAN}

\section{a. Kadar Abu}

Hasil pengkuran kadar abu pupuk kompos dengan metode takakura dapat dilihat pada Gambar 1 berikut.

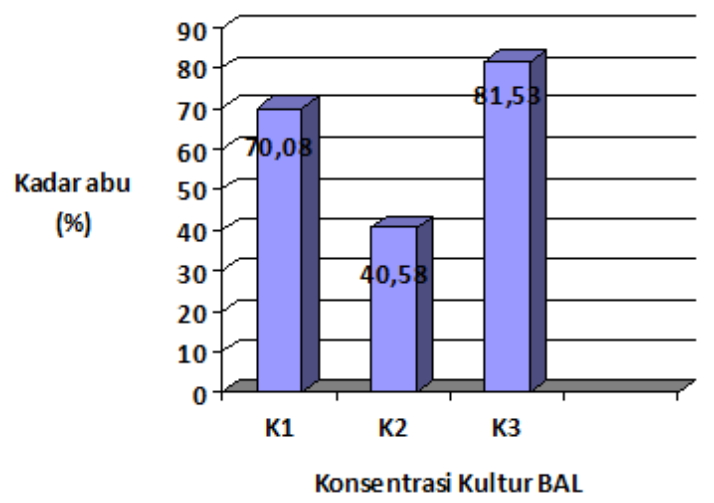

Gambar 1. Kadar abu pupuk kompos

Pada Gambar 1 dapat dilihat bahwa rata-rata kadar abu berkisar antara $40.58-81.53 \%$. Kadar abu tertinggi terdapat pada perlakuan K3 konsentrasi kultur BAL $40 \%$ yaitu sebesar $81.53 \%$. peningkatan kadar abu pada perlakuan K3 disebabkan karena proses dekomposisi yang dilakukan oleh mikroorganisme dekomposer yang berasal dari kultur Bakteri Asam Laktat (BAL).

Rendahnya kadar abu pada perlakuan K2 yaitu sebesar $40.58 \%$ disebabkan karena kemungkinan terjadinya endapan sehingga sebagian besar unsur mineral pada pupuk kompos tidak terdeteksi pada saaat pengujian.

Tabel 1. Pengaruh variasi suhu terhadap kadar abu kompos

\begin{tabular}{ll}
\hline Kode Perlakuan & Rata-Rata \\
\hline $\mathrm{S}_{1}$ & $63,98^{\mathrm{a}}$ \\
$\mathrm{S}_{2}$ & $65,81^{\mathrm{b}}$ \\
$\mathrm{S}_{3}$ & $62,40^{\mathrm{c}}$ \\
\hline
\end{tabular}

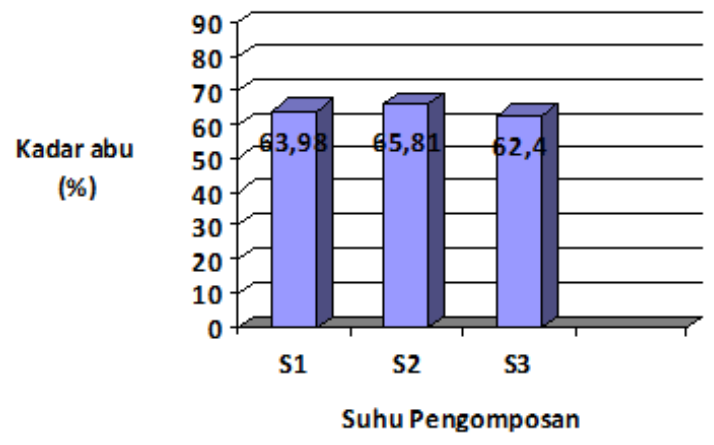

Gambar 2. Kadar abu pupuk kompos
Pada gambar 2 dapat dilihat bahwa rata-rata kadar abu berkisar antara 62,4 - 65,84\%. kadar abu tertinggi terdapat pada perlakuan $\mathrm{K} 2$ suhu pengomposan $50^{\circ} \mathrm{C}$ yaitu sebesar $65,81 \%$. Range kadar abu antar perlakuan tidak signifikan. Hal ini menunjukkan bahwa suhu pengomposan tidak memberikan pengaruh ynag nyata terhadap kadar abu yang dihasilkan.

Jumlah mineral yang dinyatakan sebagai kadar abu pada pupuk kompos ditentukan oleh jumlah bahan baku pembuat kompos yang digunakan. Jumlah bahan baku yang digunakan dalam pembuatan kompos sama untuk setiap perlakuan sehingga kadar abu yang dihasilkan tidak berbeda jauh antar perlakuan.

\section{b. Kadar Air}

Kadar air sangat berpengaruh dalam mempercepat terjadinya perubahan dan penguraian bahan-bahan organik yang digunakan dalam pembuatan kompos. Kadar air adalah presentase kandungan air dari suatu bahan yang dapat dinyatakan berdasarkan berat basah (wet basis)atau berdasarkan berat kering (dry basis)(Widarti,dkk.,2015). Pengujian kadar air kompos dilakukan menggunakan basis basah. Nilai rata-rata kadar air kompos dapat dilihat pada Tabel 3.

Tabel 2. Pengaruh variasi konsentrasi kultur kering BAL terhadap kadar air kompos

\section{Kode Perlakuan Rata-rata}

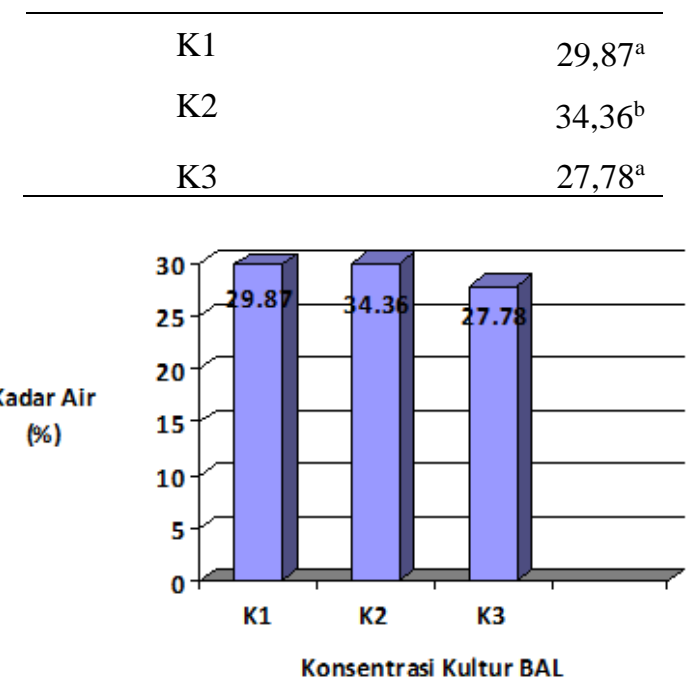

Gambar 3. Kadar air pupuk kompos

Berdasarkan Gambar 3 di atas perlakuan K2 berbeda nyata terhadap kadar air kompos namun K1 dan K3 tidak saling berbeda nyata. Hal ini dikarenakan pada perlakuan K2 jumlah mikroba 
yang mendekomposisi bahan organik masih bekerja dalam menghasilkan asam-asam organik. Menurut SNI kompos kadar air maksimal 50\% sedangkan batas minimalnya tidak ada. Kandungan air dibawah $30 \%$ reaksi biologis akan berjalan lambat dan dapat mengakibatkan berkurangnya populasi mikroorganisme pengurai karena terbatasnya habitat yang ada. Namun sebaliknya, kadar air yang terlalu tinggi menyebabkan ruang antar partikel menjadi penuh oleh air dapat menghambat aktivitas mikroorganisme, sehingga menimbulkan bau. Sedangkan nilai rata-rata kadar air kompos akibat pengaruh pemberian pengaruh suhu dapat dilihat pada Tabel 3.

Tabel 3. Pengaruh Variasi suhu terhadap kadar air kompos

\begin{tabular}{cc} 
Kode Perlakuan & Rata-Rata \\
\hline SI & 30,89 \\
S2 & 30,91 \\
S3 & 30,21 \\
\hline
\end{tabular}

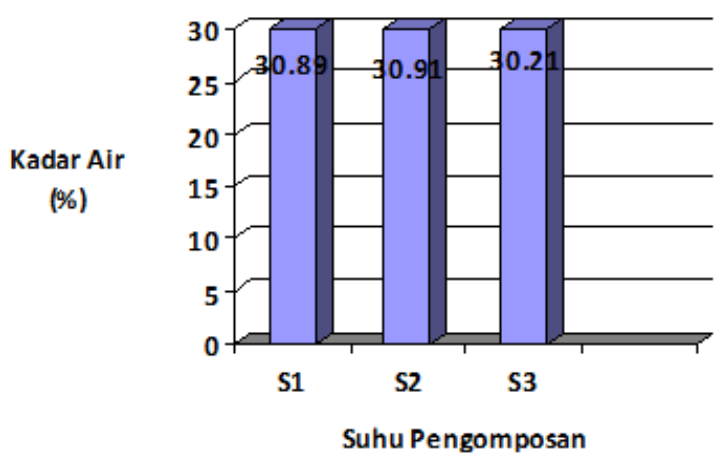

Gambar 4. Kadar air pupuk kompos

Berdasarkan Gambar 4 di atas semua perlakuan suhu tidak berpengaruh nyata terhadap kadar air kompos. Suhu mempengaruhi jenis mikrorganisme yang hidup di dalam media. Suhu poengomposan yang dicapai dalam penelitian ini sekitar $\pm 30^{\circ} \mathrm{C}$ dan berlangsung secara optimal sampai hari ke-30. Menurut Ruskandi (2006) dalam proses pengomposan aerobik terhadap dua fase yaitu fase mesofilik $23-45^{\circ} \mathrm{C}$ dan fase termofilik $45-65^{\circ} \mathrm{C}$. Kisaran temperatur ideal tumpukan kompos adalah $55-65^{\circ} \mathrm{C}$. Kisaran temperatur ideal tumpukan kompos adalah $55-65^{\circ} \mathrm{C}$.

Kadar air mempengaruhi laju dekomposisi dan suhu karena mikroorganisme membutuhkan kadar air yang optimal untuk menguraikan material organik. Pada penelitian ini pengaruh kadar air terhadap suhu kompos tidak begitu terlihat karena kadar air yang ditentukan masuk dalam skala kadar air optimum untuk pengomposan

\section{c. Kadar pH}

Hasil pengkuran $\mathrm{pH}$ pupuk kompos dengan metode takakura dapat dilihat pada tabel berikut. Tabel 4. Pengaruh variasi konsetrasi Kultur BAL terhadap pH Pupuk kompos

\begin{tabular}{ll}
\hline Kode Perlakuan & Rata-Rata \\
\hline $\mathrm{K}_{1}$ & $9,92^{\mathrm{a}}$ \\
$\mathrm{K}_{2}$ & $10,35^{\mathrm{b}}$ \\
$\mathrm{K}_{3}$ & $8,90^{\mathrm{c}}$ \\
\hline
\end{tabular}

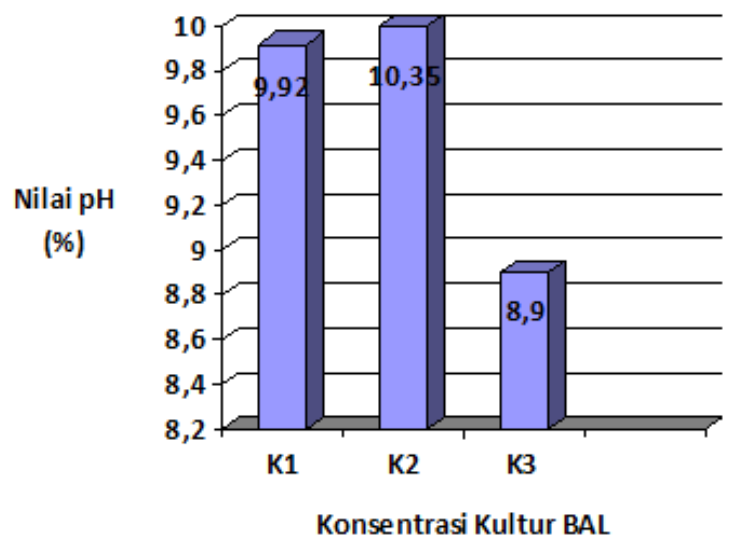

Gambar 5. Nilai pH pupuk Kompos

Berdasarkan Gambar 5 diatas menunjukkan bahwa pupuk kompos dengan perlakuan konsentrasi kultur BAL 30\% tidak memberikan pengaruh yang signifikan terhadap $\mathrm{pH}$ pupuk kompos yaitu 10,35 atau masuk dalam kategori bersifat Basa. Hal ini diduga karena range konsentrasi yang digunakan tidak cukup besar antara perlakuan K1 dan K2 . Berbeda dengan perlakuan K3 dengan Konsentrasi kultur BAL 40\%, yang berarti jumlah sumber makanan bagi mikroorganisme (karbohidrat) yang ditambahkan lebih banyak sehingga sehingga aktivitas pembentukan asam laktat lebih tinggi yang menyebabkan pupuk kompos mengalami penurunan pH cukup besar menjadi 8,9, hal ini kemungkinan disebabkan karena adanya aktivitas bioaktivator dari Kultur BAL yang ditambahkan yang memmang memiliki sifat asam dan karena adanya aktivitas mikroba yang terlibat dalam proses fermentasi bakteri asam laktat. Proses penguraian C-organik menjadi asam-asam organic menyebabkan menurunnya $\mathrm{pH}$ pupuk organic cair yang disebabkan karen adanya bakteri asam laktat (BAL) yang menghasilkan asam organic seperti asam laktat. Asam ini berasal dari penguraian karbohidrat (Dwicaksono, 2013).

Pengaruh terhadap $\mathrm{pH}$ pada pupuk sangat penting gunanya untuk menentukan penyerapan ion- 
ion unsur hara oleh tanaman. Umumnya unsur hara akan mudah diserap tanaman pada $\mathrm{pH}$ 6-7, karena pada $\mathrm{pH}$ tersebut sebagian besar unsur hara akan mudah larut dalam air. Apabila pupuk diaplikasikan dan menyebabkan tanah menjadi asam maka akan banyak ditemukan unsur alumunium (Al) yang dapat meracuni tanaman dan mengikat fosfor sehingga tidak dapat diserap tanaman, sedangkan dalam kondisi basa akan banyak ditemukan unsur $\mathrm{Na}$ (Natrium) dan Mo (Molibdenum) yang dapat meracuni tanaman. Kondisi pH juga menentukan perkembangan mikroorganisme, pada $\mathrm{pH}$ 5,5 - 7 jamur dan bakteri pengurai bahan organik akan tumbuh dengan baik (Sundari dkk, 2014).

Tabel 5. Pengaruh variasi suhu pengomposan terhadap pH Kompos

\begin{tabular}{ll}
\hline Kode Perlakuan & Rata-Rata \\
\hline $\mathrm{S}_{1}$ & $9,75^{\mathrm{a}}$ \\
$\mathrm{S}_{2}$ & $9,70^{\mathrm{b}}$ \\
$\mathrm{S}_{3}$ & $9,73^{\mathrm{c}}$ \\
\hline
\end{tabular}

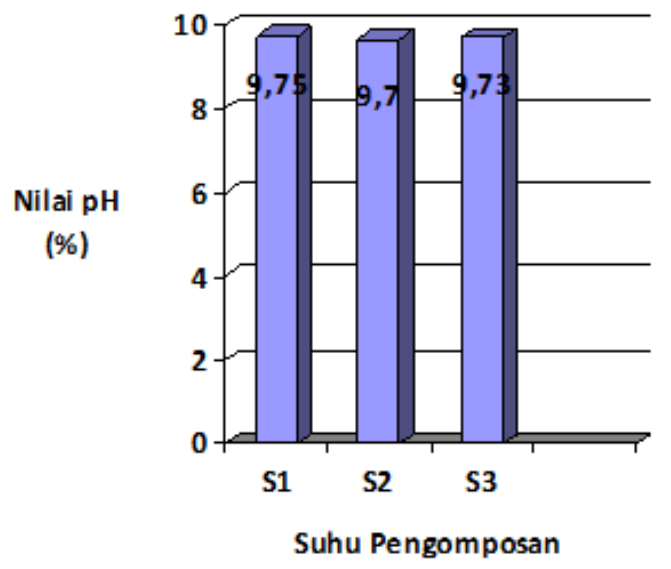

Gambar 6. Nilai pH pupuk Kompos

Pada Gambar 6 terlihat bahwa nilai $\mathrm{pH}$ pupuk kompos yang dihasilkan berada pada kisaran 9.7- 9.75 atau bersifat basa. Variasi suhu pengomposan memberikan pengaruh tidak terlalu signifikan atau tidak berpengaruh terhadap $\mathrm{pH}$ pupuk kompos yang dihasilkan. Proses pengomposan melibatkan mikroorganisme termofilik yang berperan mendegradasi bahan organic. Pada awal hingga pertengahan proses pematangan kompos akan hadir mikroorganisme termofilik yang dapat hidup pada kisaran suhu $45^{\circ} \mathrm{C}$ - $6^{0}$ C. Mikroorganisme ini mengkonsumsi karbohidrat serta protein bahan kompos (Cahaya \& Nugroho ,2008). Pada awal pengomposan, suhu pengomposan mengalami kenaikan yang menandakan adanya aktivitas mikroorganisme dengan adanya sumber makanan berupa karbohidrat dan lambat laun suhu akan menurun seiring berkurangnya sumber makanan bahan organic yang dapat diuraikan oleh mikroba yang menandakan kompos sudah matang.

Menurut Indriani (2011) Suhu proses pengomposan terbaik adalah $30^{\circ} \mathrm{C}-50^{\circ} \mathrm{C}$. Menurut kriteria SNI (BSN, 2004), suhu ideal proses pengomposan maksimal $50^{\circ} \mathrm{C}$, peningkatan suhu selama proses pengomposan diakibatkan karena tingginya aktivitas mikroorganisme pengurai. (Wahyono \& Sahwan, 2008).

Umunya $\mathrm{pH}$ dipengaruhi oleh keberadaan nitrogen dan kondisi anaerobic. Hal ini diakibatkan oleh karena sejumlah jasad renik jenis tertentu akan mengubah sampah organik menjadi asam organik. Proses selanjutnya jasad renik jenis lainnya akan memakan asam organik tersebut sehingga menyebabkan tingkat $\mathrm{pH}$ naik kembali, mendekati netral. Selanjutnya mengalami kenaikan hingga $\mathrm{pH}$ menjadi basa (Ratna dkk, 2017).

\section{KESIMPULAN DAN SARAN}

Berdasarkan uraian pembahasan, dapat disimpulkan bahwa kadar abu terbaik dengan variasi konsentrasi kultur BAL pada perlakuan K3 $(81,53 \%)$, variasi suhu $(65,81 \%)$; Kadar air terbaik dengan variasi konsentrasi kultur BAL pada perlakuan K3 (27,78\%), variasi suhu S3 $(65,81 \%)$; namun untuk nilai $\mathrm{pH}$ pada kompos tidak sesuai dengan SNI kompos.

\section{DAFTAR PUSTAKA}

BSN [Badan Standarisasi Nasional]. (2004). Spesifikasi Kompos dari Sampah Organik Domestik. SNI 19-7030-2004.

Cahaya, A., \& D. A, Nugroho. (2008). Pembuatan Kompos dengan Menggunakan Limbah Padat Organik (Sampah Sayur dan Ampas Tebu). Jurnal Fakultas Tehnik, Universitas Diponegoro.

Dwicaksono, Marsetyo Ramadhany Bagus. Bambang Suharto dan Liliya Dewi Susanawati. 2013. Pengaruh Penambahan Effective Microorganisms pada Limbah Cair Industri Perikanan Terhadap Kualitas Pupuk Cair Organik. Jurnal Sumberdaya Alam \& Lingkungan. Universitas Brawijaya. Malang.

Indriani, Y. H. (2011). Membuat Kompos Secara Kilat. Jakarta: PT. Penebar Swadaya.

Ratna, D. A. P., Samudro, G dan S. Sumiyati. 2017. Pengaruh Kadar Air Terhadap Proses Pengomposan Sampah Organik Dengan Metode Takakura. Jurnal Teknik Mesin (JTM): Vol. 06.

Ruskandi. 2006. Pembuatan Kompos Limbah Kebun Pertanaman Kelapa Polikultur. Buletin Teknik Pertanian 11(1):33-36.

Sundari, I., Maruf,W.F.dan E.N. Dewi, 2014. Pengaruh Penggunaan Bioaktivator EM4 dan Penambahan Tepung Ikan Terhadap 
Spesifikasi Pupuk Organik Cair Rumput Laut Gracilaria Sp. Jurnal Pengolahan dan Bioteknologi Hasil Perikanan

Vol. 3 No. 3.

Widarti, Budi Nining. 2015. Pengaruh Rasio C/N Bahan Baku pada Pembuatan Kompos Dari Kubis dan Kulit Pisang. Samarinda 